\title{
EFFECTS OF VITAMIN C SUPPLEMENTATION ON THE CHRONIC PHASE OF CHAGAS DISEASE
}

\author{
Ricardo Guimarães MARIM(1), Alex Silva de GUSMÃO(1), Roberto Esteves Pires CASTANHO(1), Rafael DEMINICE(3), Altino Luiz Silva THEREZO(2), \\ Alceu Afonso JORDÃo JÚNIOR(3), Marcos Renato de ASSIS(4), Elane de Fátima TAIPEIRO(5) \& Luciamare Perinetti Alves MARTINS(1)
}

\begin{abstract}
SUMMARY
Introduction: In order to examine the effectiveness of vitamin C (ascorbic acid) in combating the oxidative insult caused by Trypanosoma cruzi during the development of the chronic phase of Chagas disease, Swiss mice were infected intraperitoneally with $5.0 \times 10^{4}$ trypomastigotes of T. cruzi QM1strain. Methods: Mice were given supplements of two different doses of vitamin C for 180 days. Levels of lipid oxidation (as indicated by thiobarbituric acid reactive substances-TBARS), total peroxide, vitamin C, and reduced glutathione were measured in the plasma, TBARS, total peroxide and vitamin $\mathrm{C}$ were measured in the myocardium and histopathologic analysis was undertaken in heart, colon and skeletal muscle. Results: Animals that received a dose equivalent to 500 $\mathrm{mg}$ of vitamin $\mathrm{C}$ daily showed increased production of ROS in plasma and myocardium and a greater degree of inflammation and necrosis in skeletal muscles than those that received a lower dose or no vitamin $\mathrm{C}$ whatsoever. Conclusion: Although some research has shown the antioxidant effect of vitamin $\mathrm{C}$, the results showed that animals subject to a $500 \mathrm{mg}$ dose of vitamin $\mathrm{C}$ showed greater tissue damage in the chronic phase of Chagas disease, probably due to the paradoxical actions of the substance, which in this pathology, will have acted as a pro-oxidant or pro-inflammatory.
\end{abstract}

KEYWORDS: Lipid peroxidation biomarkers; Chagas disease; Parasitemia; Inflammation; Ascorbic acid; ROS; RNS

\section{INTRODUCTION}

Chagas disease is an anthropozoonosis caused by Trypanosoma cruzi, a flagellate protozoan ${ }^{9}$ that infects approximately $12-14$ million people in Latin America ${ }^{15}$. After contact with the parasite, patients develop the acute phase of the illness, which may be asymptomatic in some individuals or may show non-specific symptoms, such as fever, tachycardia, weakness, and lymphadenopathy. This evolves into an indeterminate phase, with no clinical signs, but with subclinical pathologies ${ }^{17}$. Many years after infection, about $30 \%$ of the patients develop the chronic phase of the disease, which has characteristic signs including megaesophagus, megacolon and cardiomegaly ${ }^{24}$. During the chronic phase, the presence of microfoci parasites leads to the constant production of interleukin-12, which activates macrophages and generates a Th1 immune response consistent with delayed hypersensitivity, which leads to tissue damage ${ }^{14,24}$.

Much of the damage to the host in Chagas disease is caused by an excess of free radicals, more specifically by the metabolism of reactive oxygen species (ROS) and reactive nitrogen species (RNS). These are produced by phagocytic cells stimulated by inflammatory mediators in tissues parasitized by $T$. cruzi. They may harm any cellular component, but the components that are affected most strongly are the cellular membranes ${ }^{18,23,42,43}$.
To combat the formation of free radicals and neutralize them before they cause damage, biological systems use molecules and enzymes such as reduced glutathione (GSH), superoxide dismutase (SOD), catalase, glutathione peroxidase (GSH-Px), and vitamin E. Others, such as vitamin $\mathrm{C}$ (ascorbic acid), glutathione reductase (GSH-Rd), and glutathione peroxidase (GSH-Px) are used to repair damage that has already been done $^{42}$.

A study by WEYERS et $a l .{ }^{44}$ showed that appropriate doses of vitamin $\mathrm{C}$ can have a preventive effect against the lipid peroxidation induced by free radicals; both those formed naturally and those caused by exogenous compounds in mice experimentally dosed with the antibacterial drug ciprofloxacin. Vitamin $\mathrm{C}$ decreased the oxidative stress on the liver and lipid peroxidation in the mouse kidney caused by this drug ${ }^{43}$. According to MAY $^{33}$, ascorbic acid's ability to reduce oxidative stress would depend on its concentration and its potential for recycling in blood and endothelium.

However researches of CHEN et al. ${ }^{11}$ showed that pharmacological doses of ascorbic acid favored the cytotoxicity of tumor cells by formation of hydrogen peroxide $\left(\mathrm{H}_{2} \mathrm{O}_{2}\right)$, leading to the decreased growth of tumors in mice due to pro-oxidant action. For LEVINE et al. ${ }^{29}$ ascorbate could be used as a treatment for viral and bacterial infections and in other human

(1) Department of Parasitology of Marília Medical School (FAMEMA), R. Dona Maria Feres 165, 17519-070 Marília, São Paulo, Brazil.

(2) Department of Pathology of Marília Medical School (FAMEMA), Av. Monte Carmelo 800, 17519-030 Marília, São Paulo, Brazil.

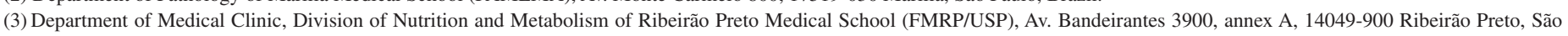
Paulo, Brazil.

(4) Department of Rheumatology of Marília Medical School (FAMEMA), Av. Monte Carmelo 800, 17519-030 Marília, São Paulo, Brazil 


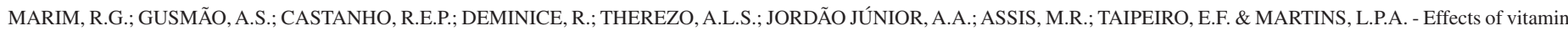
C supplementation on the chronic phase of Chagas disease. Rev. Inst. Med. Trop. Sao Paulo, 57(3): 245-50, 2015.

pathogens, where the production of $\mathrm{H}_{2} \mathrm{O}_{2}$ and ROS could be beneficial in disease progression.

A study by MAÇAO et al. ${ }^{30}$ showed that oxidative stress was controlled in the myocardium of patients in the chronic phase of Chagas disease when $500 \mathrm{mg}$ of vitamin $\mathrm{C}$ and $800 \mathrm{UI}$ of vitamin $\mathrm{E}$ were administered daily for a six-month period, probably as a consequence of vitamin E consumption and antioxidant protection. According to KOURY \& DONANGELO ${ }^{28}$, vitamins C and E are important "street sweepers" of free radicals.

Nonetheless, $\mathrm{CHEN}^{10}$ noted that with a lower concentration of vitamin $\mathrm{E}$, the administration of high doses of vitamin $\mathrm{C}$ appears to promote lipid peroxidation and significantly decreases the animals' antioxidant potential.

Based on these studies, the authors decided to investigate the effectiveness of vitamin $\mathrm{C}$ in combating the oxidative insult caused by progressive $T$. cruzi inflammation during the evolution of Chagas disease in its chronic phase, by administering two different daily dosages of vitamin C to mice experimentally infected with the T. cruzi QM1strain, since the common sense of its role in antioxidant defense makes its use indiscriminate among people, including chronic carriers of Chagas disease.

\section{MATERIALS AND METHODS}

Infection of mice: Thirty 20-day-old male "Swiss" mice, weighing on average 13 grams, were intraperitoneally infected with $5.0 \times 10^{4}$ trypomastigotes of $T$. cruzi $\mathrm{QM} 1$ strain $^{32}$ via blood from other previouslyinfected mice, which was obtained by cardiac puncture into heparin. The trypomastigotes were counted following the BRENER ${ }^{6}$ method and the intraperitoneal infection was performed by inoculating $0.1 \mathrm{~mL}$ of blood using an Injex ${ }^{\circledR}$ insulin syringe. Following this procedure, three groups of 10 mice were chosen at random and named $\mathrm{P}$ (placebo), Vit $\mathrm{C} 60$ (mice that received the dose of vitamin C (D60); see next section for the doses given), and Vit C 500 (mice that received a dosage of vitamin C (D500)). The animals were kept in individual cages to facilitate handling and fed with the standard Nuvilab CR-1® diet, which is composed of: ground whole corn, soybean meal, wheat bran, calcium carbonate, calcium phosphate, sodium chloride, vegetable fat, mineral vitamin premix, amino acid, and water ad libitum.

Calculation of vitamin C dosage and treatment: Vit C 60 group (a D60 dose) was given a daily dose of $60 \mathrm{mg}$ of vitamin $\mathrm{C}$, equal to the average weight of the mice $\times\left(8.6 \times 10^{-4} \mathrm{mg}\right.$ per gram of weight $)$, diluted in $10 \mu \mathrm{L}$ of human mineral water (Soft巴). Vit C 500 group (a D500 dose) was given a daily dose of $500 \mathrm{mg}$ of vitamin $\mathrm{C}$, equal to the average weight of the mice $\times\left(7.14 \times 10^{-3} \mathrm{mg}\right.$ per gram of weight $)$ diluted in 10 $\mu \mathrm{L}$ of human mineral water ( $\mathrm{Soft} \circledast$ ). The $\mathrm{P}$ group was a placebo group: each animal received $10 \mu \mathrm{L}$ of human mineral water (Soft@) daily. Every morning, all mice were treated orally with $10 \mu \mathrm{L}$ of vitamin C (D60 or D500) in mineral water or mineral water (Soft $\left.{ }^{\circledR}\right)$ alone, using a Gilson automatic pipette. The three groups were treated for 180 days, starting from the infection date. Vitamin $\mathrm{C}$ used in this research was Cewin® (in drops doses) from Sanifi-Aventis Laboratory.

Histopathologic analysis: A fragment of heart, colon and skeletal thigh muscle from all mice that survived was collected on the $180^{\text {th }}$ day after infection for histopathologic analysis after $\mathrm{CO}_{2}$ euthanasia ${ }^{22}$. The tissues were embedded in paraffin and $5 \mu \mathrm{m}$ sections were stained with hematoxylin-eosin and examined under a light microscope at a magnification of $400 \times$. Five sequential histological sections were examined for each fragment, and the fragments were analyzed and graded for inflammation and amastigote nests for a total of 10 high magnification fields for each type of tissue. The investigator examining the sections was unaware of the grouping of the mice.

A semi-quantitative scale of one to three plus signs was used in order to grade the inflammatory process and the number of amastigote nests. This way, inflammation and/or necrosis were examined separately to the number of amastigotes for each animal: "+" signified mild inflammation, necrosis and rare amastigote nests; " ++ " moderate inflammation, necrosis and moderate number of amastigote nests; and "+++", intense inflammation, necrosis and frequent amastigote nests.

Biochemistry: Blood samples were collected on the $180^{\text {th }}$ day after infection. The mice were exposed to $\mathrm{CO}_{2}\left(100 \% \mathrm{CO}_{2}\right)$ for a few seconds as a form of anesthetizing them, and then the blood was collected by cardiac puncture into heparin. This method of euthanasia was chosen as studies conducted by GODIN \& GARNETT ${ }^{22}$ and BILLERT \& DROBNICK $^{5}$ show that exposure to this gas may not increase oxidative damage to tissues.

Blood was centrifuged at $1500 \mathrm{~g}$ immediately after collection and the plasma stored at $-80^{\circ} \mathrm{C}$. For the measurement of vitamin $\mathrm{C}, 200 \mu \mathrm{L}$ plasma samples were immediately acidified with $800 \mu \mathrm{L} \mathrm{5 \%}$ trichloroacetic acid and stored at $-80^{\circ} \mathrm{C}$ for later analysis. One fragment of heart muscle from each mouse was immediately frozen in liquid nitrogen and subsequently stored at $-80^{\circ} \mathrm{C}$. Oxidative stress markers were determined around 3 - 5 weeks after sampling. All samples were stored at $-80^{\circ} \mathrm{C}$ before analysis.

Thiobarbituric acid reactive substances (TBARS) were used as biomarkers of lipid peroxidation in plasma and heart muscle and measured using a method adapted from COSTA et al. ${ }^{13}$. The total concentration of TBARS was determined by the difference in absorbance between samples and in a standard solution of malondialdehyde. The total peroxide in the cardiac muscle and plasma was determined using the FOX method, as described by SÖDERGREN et al. ${ }^{38}$. This method uses a comparison with the standard curve of $\mathrm{H}_{2} \mathrm{O}_{2}$. Quantification of plasma glutathione was performed by adapting the method described by COSTA et al. ${ }^{13}$ using the standard curve of GSH.

The vitamin $\mathrm{C}$ concentration in plasma and heart muscle was determined according to BESSEY's ${ }^{4}$ method, $100 \mu \mathrm{L}$ of a solution containing 2,4-dinitrophenylhydrazine (2\%), thiourea (5\%), and copper sulfate $(0.6 \%)$ in sulfuric acid $(25 \%)$ added to $300 \mu \mathrm{L}$ of acidified plasma. After a 4-hour incubation in a $37^{\circ} \mathrm{C}$ water bath, $200 \mu \mathrm{L}$ sulfuric acid $(65 \%)$ was added and the solution was incubated for $20 \mathrm{~min}$ at room temperature. Reading was performed on a spectrophotometer (Spectramax M5, Molecular Devices) at $520 \mathrm{~nm}$ and compared with the standard curve of vitamin C.

Statistics: The results were analyzed by Normality Test (ShapiroWilks) to verify that the data followed a normal distribution and homogeneity of variances in the groups of Levene's test. Statistical inference was performed using ANOVA one-way and Post-hoc analyses 


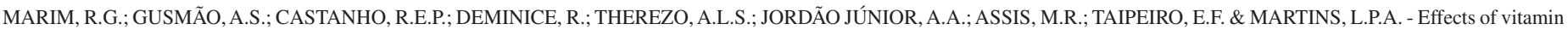
C supplementation on the chronic phase of Chagas disease. Rev. Inst. Med. Trop. Sao Paulo, 57(3): 245-50, 2015.

were performed with the Tukey (HSD) test ${ }^{1}$. The significance level used was $5 \%$.

This study was approved by the Ethics Committee of the Faculty of Medicine of Marília (FAMEMA) under number 133/10. The manner of treatment, care, and euthanasia of mice followed the standards set by Colégio Brasileiro de Experimentação Animal/Brazilian College of Animal Experimentation (Cobea) ${ }^{39}$.

\section{RESULTS}

After 180 days of treatment two animals had died in the placebo group, three had died in group Vit C 60, and four had died in group Vit C 500. The study was therefore performed on eight animals in group P, seven in group Vit C 60, and six in group Vit C 500. Group Vit C 500 suffered greater damage to the skeletal muscle, showing a greater degree of inflammation than group Vit C 60 and a greater degree of necrosis than group $\mathrm{P}$ (Table 1). With regards to cardiac muscle and the colon, all animals in group Vit C 500 had inflammation, with mice of this group showing a greater level of damage.

An analysis of TBARS, total peroxide, vitamin C, and plasma GSH is shown in Table 2 and an analysis of TBARS, total peroxide and vitamin C in the myocardium is shown in Table 3 . Group $\mathrm{P}$ had lower total peroxide concentrations in plasma than group Vit C $500(p=0.021$, Table 2$)$. The TBARS analysis in plasma showed a statistically significant difference between group $\mathrm{P}$ and group Vit C 500 ( $p=0.021$, Table 2$)$, and between group Vit C 60 and group Vit C 500 ( $p=0.022$, Table 2). There was no statistically significant difference between the groups in the plasma GSH $(p>0.05$, Table 2).

There was a higher total production of peroxides in the myocardium of group Vit $\mathrm{C} 500$ than in group $\mathrm{P}(p=0.050$, Table 3$)$. TBARS analysis (lipid oxidation levels) in the myocardium showed no statistically significant differences between the dosages.

The vitamin $\mathrm{C}$ results showed no statistical differences in plasma and myocardium between the three groups with $p>0.05$ for all comparisons.

\section{DISCUSSION}

To date, no research has been done to test the effectiveness of vitamin $\mathrm{C}$ in combating ROS and RNS produced during the evolution of Chagas disease. This study has shown that oral administration of $500 \mathrm{mg}$ of vitamin C, per 180 days, in mice infected with $T$. cruzi can be harmful to the host, leading to increased total peroxide and TBARS, which may increase the severity of lesions, characteristic of chronic phase of this disease.

In this study, the vitamin $C$ doses of $60 \mathrm{mg}$ and $500 \mathrm{mg}$ provided to groups Vit C 60 and Vit C 500 resulted in no statistically significant differences in myocardial and plasma vitamin $\mathrm{C}$ concentrations relative to group $\mathrm{P}$ ( $p>0.05$ in all comparisons). The absence of differences between experimental groups in these results at the time of plasma and tissue collection could be explained by the physiological mechanism of control of concentrations of vitamin $\mathrm{C}$, where ascorbate concentrations in plasma and tissue are tightly controlled. According to LEVINE et al. ${ }^{29}$, the vitamin $\mathrm{C}$ concentration was tightly controlled by absorption, tissue transport and renal reabsorption and excretion.

Surprisingly, the dosage of $500 \mathrm{mg}$ caused detrimental repercussions to the host. This is confirmed by the study's results regarding the number of mice that survived the treatment and the histopathologic findings, in which group Vit C 500 was shown to have suffered greater skeletal, cardiac muscle and colonic tissue damage, causing the death of a large number of animals.

Table 1

Degree of histopathologic lesions and parasitism in mice infected by T. cruzi QM1 and treated with two different doses of vitamin C (VitC60= D60; VitC500= D500) and placebo (P): (+) mild inflammation, necrosis and rare amastigote nests; (++) moderate inflammation, necrosis and moderate number of amastigote nests; (+++) intense inflammation, necrosis and frequent amastigote nests. *\%" indicates the percentage of infected mice affected by necrosis or inflammation in each group, and the absolute number observed is given in parentheses

\begin{tabular}{|c|c|c|c|c|c|c|c|c|c|c|}
\hline & & \multicolumn{3}{|c|}{$\mathbf{P}$} & \multicolumn{3}{|c|}{ VitC60 } & \multicolumn{3}{|c|}{ VitC500 } \\
\hline & & Inflammation & $\begin{array}{c}\text { Amastigote } \\
\text { nests }\end{array}$ & Necrosis & Inflammation & $\begin{array}{c}\text { Amastigote } \\
\text { nests }\end{array}$ & Necrosis & Inflammation & $\begin{array}{c}\text { Amastigote } \\
\text { nests }\end{array}$ & Necrosis \\
\hline & & $\%(8)$ & $\%(8)$ & $\%(8)^{*}$ & $\%(7)$ & $\%(7)$ & $\%(7)$ & $\%(6)$ & $\%(6)$ & $\%(6)$ \\
\hline \multirow{3}{*}{$\begin{array}{l}\text { Skeletal } \\
\text { muscle }\end{array}$} & + & $12.5 \%$ & - & $50.0 \%(4)$ & - & - & $42.6 \%(3)$ & $50.0 \%(3)$ & - & $100 \%(6)$ \\
\hline & ++ & - & - & - & - & - & $14.3 \%(1)$ & - & - & - \\
\hline & +++ & - & - & - & - & - & - & - & - & - \\
\hline \multirow{3}{*}{$\begin{array}{l}\text { Cardiac } \\
\text { muscle }\end{array}$} & + & $50.0 \%$ (4) & $12.5 \%$ & - & $85.7 \%(6)$ & - & - & $50.0 \%(3)$ & - & - \\
\hline & ++ & $25.0 \%(2)$ & - & - & - & - & - & $50.0 \%(3)$ & - & - \\
\hline & +++ & - & - & - & - & - & - & - & - & - \\
\hline \multirow{3}{*}{ Colon } & + & $62.5 \%(5)$ & - & - & $42.9 \%(3)$ & $28.6 \%(2)$ & - & $50.0 \%(3)$ & - & - \\
\hline & ++ & $25.0 \%$ & - & - & $28.6 \%(2)$ & - & - & $50.0 \%(3)$ & - & - \\
\hline & +++ & - & - & - & - & - & - & - & - & - \\
\hline
\end{tabular}


MARIM, R.G.; GUSMÃO, A.S.; CASTANHO, R.E.P.; DEMINICE, R.; THEREZO, A.L.S.; JORDÃO JÚNIOR, A.A.; ASSIS, M.R.; TAIPEIRO, E.F. \& MARTINS, L.P.A. - Effects of vitamin

C supplementation on the chronic phase of Chagas disease. Rev. Inst. Med. Trop. Sao Paulo, 57(3): 245-50, 2015.

Table 2

Mean values and standard deviation of thiobarbituric acid reactive substances (TBARS), total peroxide, vitamin C and reduced glutathione (GSH) in plasma of mice treated with two different doses of vitamin $\mathrm{C}(\mathrm{VitC60}=\mathrm{D} 60$; VitC500= D500) and placebo (P) during the chronic phase of experimental infection by $T$. cruzi QM1.

$(\mathrm{SD}=$ standard deviation)

\begin{tabular}{|c|c|c|c|c|}
\hline Variable & $P$ & VitC60 & VitC500 & Compared Groups \\
\hline TBARS $(\mu \mathrm{mol} / \mathrm{L})$ & $34.8(\mathrm{SD}=2.5)$ & $34.8(\mathrm{SD}=2.8)$ & $41.0(\mathrm{SD}=6.1)$ & $\begin{array}{c}\text { P \& VitC60 } \\
\text { P \& VitC500* } \\
\text { VitC60 \&VitC500* }\end{array}$ \\
\hline $\begin{array}{l}\text { Total peroxide }\left(\mu \mathrm{mol} \mathrm{H}_{2} \mathrm{O}_{2}\right. \\
\text { equivalent } / \mathrm{L})\end{array}$ & $88.4(\mathrm{SD}=35.2)$ & $134.3(\mathrm{SD}=38.1)$ & $148.6(\mathrm{SD}=40.0)$ & $\begin{array}{c}\text { P \& VitC60 } \\
\text { P \& VitC500* } \\
\text { VitC60 \& VitC500 }\end{array}$ \\
\hline Vitamin C (mg/dL) & $0.28(\mathrm{SD}=0.07)$ & $0.29(\mathrm{SD}=0.07)$ & $0.33(\mathrm{SD}=0.04)$ & $\begin{array}{c}\text { P \& VitC60 } \\
\text { P \& VitC500 } \\
\text { VitC60 \& VitC500 }\end{array}$ \\
\hline GSH (mmol/L) & $237.13(\mathrm{SD}=29.45)$ & $203.30(\mathrm{SD}=46.77)$ & $183.32(\mathrm{SD}=25.59)$ & $\begin{array}{c}\text { P \& VitC60 } \\
\text { P \& VitC500 } \\
\text { VitC60 \& VitC500 }\end{array}$ \\
\hline
\end{tabular}

* Groups differ by Tukey test at $5 \%$ probability.

Table 3

Mean values and standard deviation of thiobarbituric acid reactive substances (TBARS), total peroxide and vitamin $\mathrm{C}$ in the myocardium of mice treated with two different doses of vitamin $\mathrm{C}($ VitC60 = D60; VitC500= D500) and placebo $(\mathrm{P})$ during the chronic phase of experimental infection by $T$. cruzi $\mathrm{QM} 1 .(\mathrm{SD}=$ standard deviation)

\begin{tabular}{|c|c|c|c|c|}
\hline Variables & $P$ & VitC60 & VitC500 & Compared Groups \\
\hline TBARS ( $\mu \mathrm{mol} / \mathrm{g}$ protein) & $82.4(\mathrm{SD}=20.3)$ & $73.6(\mathrm{SD}=14.3)$ & $100.4(\mathrm{SD}=27.1)$ & $\begin{array}{c}\text { P \& VitC60 } \\
\text { P \& VitC500 } \\
\text { VitC60 \& VitC500 }\end{array}$ \\
\hline $\begin{array}{l}\text { Total peroxide }\left(\mu \mathrm{mol} \mathrm{H}_{2} \mathrm{O}_{2}\right. \\
\text { equivalent/g protein) }\end{array}$ & $161.4(\mathrm{SD}=82.3)$ & $304.1(\mathrm{SD}=172.7)$ & $368.4(\mathrm{SD}=188.6)$ & $\begin{array}{c}\text { P \& VitC60 } \\
\text { P \& VitC500* } \\
\text { VitC60 \&VitC500 }\end{array}$ \\
\hline Vitamin C ( $\mu \mathrm{g} / \mathrm{g}$ prot) & $6.61(\mathrm{SD}=1.13)$ & $6.76(\mathrm{SD}=0.74)$ & $6.97(\mathrm{SD}=0.76)$ & $\begin{array}{c}\text { P \& VitC60 } \\
\text { P \& VitC500 } \\
\text { VitC60 \& VitC500 }\end{array}$ \\
\hline
\end{tabular}

* Groups differ by Tukey test at 5\% probability.

Corroborating the histopathologic findings, a greater total peroxide production in group Vit $\mathrm{C} 500$ than in group $\mathrm{P}$ was observed, both in plasma $(p=0.021)$ and in the myocardium $(p=0.050)$, as well as an increase in plasma TBARS concentrations in group Vit C $500(p=0.021)$. Although a tendency of decrease in GSH concentration of group Vit C 500 was observed, suggesting that antioxidant response was activated to neutralize ROS and RNS during disease progression, these results were not statistically significant.

Researches of MAÇAO et al. ${ }^{30}$ demonstrated a decrease in TBARS and increase in GSH when chronic chagasic patients were supplemented daily with $500 \mathrm{mg}$ vitamin $\mathrm{C}$ and $800 \mathrm{IU}$ vitamin $\mathrm{E}$. The effectiveness of these antioxidants has been studied by various authors ${ }^{3,46}$, who indicated that both vitamins $\mathrm{C}$ and $\mathrm{E}$ operate in the context of an integrated system in which the overall antioxidant status is under homeostatic control, so that the change in status of a single antioxidant may affect the status of the other in a way that the ratio $\mathrm{C} / \mathrm{E}$ can be of central importance to antioxidant protection ${ }^{21}$.
Nevertheless, the aim of this study was to evaluate the effects of the isolated uses of ascorbic acid. These results show that daily supplementation, only with the equivalent of $500 \mathrm{mg}$ of vitamin $\mathrm{C}$, is coupled with a statistically significant increase in production of free radicals and lipid peroxidation between Vit C 60 Vit C $500(p=0.022)$, as shown by the result.

Although the antioxidant properties of vitamin $\mathrm{C}$ are well established $^{2,20,26}$, it is still debatable that it beholds a possible prooxidant $^{8,16,37}$ and an anti / pro-inflammatory effect ${ }^{27,34}$.

In vitro studies performed by CLEMENT et al. ${ }^{12}$, showed that, in high concentrations, vitamin $\mathrm{C}$ can exert a pro-oxidant effect before antioxidant, but in vivo the biological relevance of these events remains controversial $^{8}$.

However, in case of an injury inflicted by these tissues, the possibility 
MARIM, R.G.; GUSMÃO, A.S.; CASTANHO, R.E.P.; DEMINICE, R.; THEREZO, A.L.S.; JORDÃO JÚNIOR, A.A.; ASSIS, M.R.; TAIPEIRO, E.F. \& MARTINS, L.P.A. - Effects of vitamin C supplementation on the chronic phase of Chagas disease. Rev. Inst. Med. Trop. Sao Paulo, 57(3): 245-50, 2015.

of free transition metal $\mathrm{Fe}^{3+}$ and $\mathrm{Cu}^{2+}$ increases, which may be reduced by ascorbate 7 . In vitro, the interaction of these reduced metals with $\mathrm{H}_{2} \mathrm{O}_{2}$ produce hydroxyl radicals and lipid alkoxyl radicals (LO), causing oxidative damage, and the ascorbate would then act as pro oxidant.

Therefore, it is possible that a high intake of vitamin $\mathrm{C}$ could be harmful to persons who have chronic inflammatory conditions ${ }^{19}$, because it would cause the interaction of these catalytically active metals with ascorbate, as in the chronic phase of Chagas disease. This would also cause damage to surrounding tissues, which contribute to the inflammatory process, besides the fact that their own ROS amplify the release of pro-inflammatory cytokines.

Although several studies in humans and other species delineate the functional significance of vitamin $\mathrm{C}$ in resistance to infection ${ }^{40,41}$, the effects of a high dose on the activity of the immune system is still scarce.

Studies of HORNIG et al. ${ }^{25}$ reported the increased bioavailability of nitric oxide in patients with chronic heart failure after arterial and oral administration of vitamin $\mathrm{C}$ and $\mathrm{NOH}$ et al. ${ }^{36}$, discovered that megadoses of vitamin $\mathrm{C}$ increased the production of interferon, IL- 2 and TNF- $\alpha$, showing a positive correlation between serum levels of vitamin $\mathrm{C}$ and pro inflammatory cytokines. Moreover, MIKIROVA et al. ${ }^{34}$ discovered that high doses of vitamin $\mathrm{C}$ reduces inflammation in patients with cancer.

These results showed an increase in the inflammatory process with the presence of vitamin $\mathrm{C}$ and, in a high dosage, an exacerbation of tissue damage. This infers that, in the chronic phase of Chagas disease, the administration of $500 \mathrm{mg}$ of vitamin $\mathrm{C}$ provides a pro-oxidant and pro-inflammatory medium to these animals. Since the effects were not observed in shorter periods of supplementation ${ }^{31}$, these results may indicate the potential risk of for patients at the chronic phase of Chagas disease in ingesting high vitamin $\mathrm{C}$ concentrations for a long period of time. These results will be elucidated through future research on the technique of immunohistochemistry and may highlight whether the exacerbation of the inflammatory process is associated with the presence of the parasite or its cell debris, or if it occurred due to the actions of vitamin $\mathrm{C}$.

Therefore, these results indicate the need for further investigation to elucidate the mechanisms whereby the high dosage of vitamin $\mathrm{C}$ may operate in the parasite ${ }^{35,45}$ or in the harmful events identified by this research.

\section{RESUMO}

\section{Efeitos da suplementação de vitamina $\mathrm{C}$ na fase crônica da doença de Chagas}

Introdução: Para verificar a eficácia da vitamina $\mathrm{C}$ em combater o insulto oxidativo causado pelo Trypanosoma cruzi durante a evolução da fase crônica da doença de Chagas, camundongos Swiss foram previamente infectados via intraperitoneal com $5.0 \times 10^{4}$ tripomastigotas da cepa QM1 de T. cruzi. Métodos: Camundongos foram suplementados com duas diferentes doses de vitamina C por 180 dias. Foram mensurados os níveis de peroxidação lipídica (indicado por substâncias reativas ao ácido tiobarbitúrico-TBARS), peróxido total, vitamina $\mathrm{C}$, e glutationa reduzida no plasma e TBARS, peróxido total e vitamina $\mathrm{C}$ no miocárdio, e foi realizado o estudo histopatológico em coração, cólon e músculo esquelético. Resultados: Animais que receberam diariamente uma dosagem equivalente a $500 \mathrm{mg}$ de vitamina $\mathrm{C}$ apresentaram aumento na produção de ROS e RNS no plasma e no miocárdio e maior grau de inflamação e necrose em músculo esquelético em comparação àqueles que receberam doses menores ou nenhuma vitamina C. Conclusão: Embora muitas pesquisas tenham mostrado o efeito antioxidante da vitamina $\mathrm{C}$, nossos resultados mostraram que os animais que foram expostos a $500 \mathrm{mg}$ de vitamina $C$ apresentaram maior dano tecidual na fase crônica da doença de Chagas, provavelmente devido a ações paradoxais desta substância, onde nesta patologia, poderá agir como pró-oxidante ou pró-inflamatória.

\section{ACKNOWLEDGEMENTS}

Statistical assistance made through the Extension Project "Statistical advice to students and teachers of undergraduate and graduate programs of FFC-CM, UNESP and external researchers," coordinated by Prof. Dr. Sebastião Marcos Ribeiro de Carvalho, Department of Educational Psychology, the FFC - Campus Marília, UNESP.

\section{CONFLICT OF INTEREST}

The authors of "Effects of vitamin C supplementation on the chronic phase of Chagas disease" declare no conflicts of interest in developing this study.

\section{FINANCIAL SUPPORT}

The authors thank the São Paulo State Foundation for Research Support (FAPESP) for financial support for this project.

\section{REFERENCES}

1. Armitage P, Berry G. Estadística para la investigación biomédica. $3^{\text {a }}$ ed. Madrid: Harcourt Brace; 1997

2. Barreiros ALBS, David JM, David PJ. Estresse oxidativo: relação entre geração de espécies reativas e defesa do organismo. Quim Nova. 2006;29:113-23.

3. Benzie IF, Strain JJ. Effect of vitamin C supplementation on concentrations of vitamins $\mathrm{C}$ and $\mathrm{E}$ in fasting plasma. Asia Pac J Clin Nutr. 1999;8:207-10.

4. Bessey OA. Ascorbic acid. Microchemical methods. In: Vitamin methods. New York: Academic Press; 1960

5. Billert H, Drobnick L. Carbon dioxide and oxidative stress. Nowiny Lekarskie 2001,70:753-62

6. Brener Z. Contribuição ao estudo da terapeutica experimental da doenca de Chagas. [Dissertação]. Belo Horizonte: Universidade Federal de Minas Gerais; 1961.

7. Buettner GR, Anne Jurkiewicz BA. Catalytic metals, ascorbate and free radicals: combinations to avoid. Radiat Res. 1996;145:532-41.

8. Carr A, Frei B. Does vitamin $\mathrm{C}$ act as a pro-oxidant under physiological conditions? FASEB J. 1999;13:1007-24.

9. Catalán LN. Enfermedad de Chagas. Acta Gastroenterol Latinoam. 2010;21:292-7.

10. Chen LH. Interaction of vitamin E and ascorbic acid. In vivo. 1989;3:199-209.

11. Chen Q, Espey MG, Sun AY, Pooput C, Kirk KL, Krishna MC, et al. Pharmacologic doses of ascorbate act as a prooxidant and decrease growth of aggressive tumor xenografts in mice. Proc Natl Acad Sci USA. 2008;105:11105-9. 
MARIM, R.G.; GUSMÃO, A.S.; CASTANHO, R.E.P.; DEMINICE, R.; THEREZO, A.L.S.; JORDÃO JÚNIOR, A.A.; ASSIS, M.R.; TAIPEIRO, E.F. \& MARTINS, L.P.A. - Effects of vitamin C supplementation on the chronic phase of Chagas disease. Rev. Inst. Med. Trop. Sao Paulo, 57(3): 245-50, 2015.

12. Clément MV, Ramalingam J, Long LH, Halliwell B. The in vitro cytotoxicity of ascorbate depends on the culture medium used to perform the assay and involves hydrogen peroxide. Antioxid Redox Signal. 2001;3:157-63.

13. Costa CM, Santos RCC, Lima EA. A simple automated procedure for thiol measurement human and serum samples. J Bras Patol Med Lab. 2006;42:345-50.

14. Cunha-Neto E, Rizzo LV, Albuquerque F, Abel L, Guilherme L, Bocchi E, et al. Cytokine production profile of heart-infiltrating $\mathrm{T}$ cells in Chagas'disease cardiomyopathy. Braz J Med Biol Res. 1998;31:133-7.

15. Dias JCP. Globalização, iniquidade e doença de Chagas. Cad Saúde Pública. 2007;23(Suppl 1):S13-S22.

16. Duarte TL, Lunec J. Review: When is an antioxidant not an antioxidant? A review of novel actions and reactions of vitamin C. Free Radic Res. 2005;39:671-86.

17. Dutra WO, Menezes CAS, Villani FNA, Costa GC, Silveira ABM, Reis DA, et al. Cellular and genetic mechanisms involved in generation of protective and pathogenic immune responses in human Chagas disease. Mem Inst Oswaldo Cruz. 2009;104(Suppl 1):208-18.

18. Ferreira ALA, Matsubara LS. Radicais livres: conceitos, doenças relacionadas, sistema de defesa e estresse oxidativo. Rev Assoc Med Bras. 1997;43:61-8.

19. Fisher AEO, Naughton DP. Vitamin C contributes to inflammation via radical generating mechanisms: a cautionary note. Medical Hypotheses. 2003;61(5-6):65760 .

20. Frei B, England L, Ames BN. Ascorbate is an outstanding antioxidant in human blood plasma. Proc Natl Acad Sci USA. 1989;86:6377-81.

21. Gey KF. Vitamins E plus C and interacting constituents required for optimal health. A critical and constructive review of epidemiology and supplementation data regarding cardiovascular disease and cancer. Biofactors. 1998;7:113-74

22. Godin DV, Garnett ME. Effects of various anesthetic regimens on tissue antioxidant enzyme activities. Res Commun Chem Pathol Pharmacol. 1994;83:93-101.

23. Gupta S, Wen JJ, Garg NJ. Oxidative stress in Chagas disease. Interdiscip Perspect Infect Dis. 2009;190354.

24. Higuchi ML, Benvenuti LA, Martins Reis M, Metzger M. Pathophysiology of the heart in Chagas disease: current status and new developments. Cardiovasc Res. 2003;60:96-107.

25. Hornig B, Arakawa N, Kohler C, Drexler H. Vitamin C improves endothelial function of conduit arteries in patients with chronic heart failure. Circulation. 1997;97:363-8.

26. Iqbal K, Khan A, Khattak MMAK. Biological significance of ascorbic acid (vitamin C) in human health: a review. Pakistan J Nutr. 2004;3:5-13.

27. Jialal I, Singh U. Is vitamin C an antiinflammatory agent? Am J Clin Nutr. 2006;83:525-6.

28. Koury JC, Donangelo CM. Zinco, estresse oxidativo e atividade física. Rev Nutr. 2003;16:433-41.

29. Levine M, Padayatty SJ, Espey MG. Vitamin C: a concentration-function approach yields pharmacology and therapeutic discoveries. Am Soc Nutr. 2011;2:78-88.

30. Maçao LB, Wilhelm Filho D, Pedrosa RC, Pereira A, Backes P, Torres MA, et al. Antioxidant therapy attenuates oxidative stress in chronic cardiopathy associated with Chagas disease. Int J Cardiol. 2007;123:43-9.
31. Marim RG, Gusmão AS, Castanho REP, Demenici R, Therezo ALS, Jordão Júnior AA, et al. Effects of vitamin C supplementation in Chagas disease acute phase on experimentally infected mice with Trypanosoma cruzi QM1 strain. Rev Inst Med Trop Sao Paulo. 2012;54:319-23.

32. Martins LPA, Marcili A, Castanho REP, Therezo ALS, Oliveira JCP, Suzuki RB, et al. Rural Triatoma rubrovaria from southern Brazil harbors Trypanosoma cruzi of lineage IIc. Am J Trop Med Hyg. 2008;79:427-34

33. May JM. How does ascorbic acid prevent endothelial dysfunction? Free Radic Biol Med. 2000;28:1421-9.

34. Mikirova N, Casciari J, Rogers A, Taylor P. Effect of high-dose intravenous vitamin $\mathrm{C}$ on inflammation in cancer patients. J Transl Med. 2012;10:189.

35. Monteiro G, Horta BB, Pimenta DC, Augusto O, Netto LE. Reduction of 1-Cys peroxiredoxins by ascorbate changes the thiol-specific antioxidant paradigm, revealing another function of vitamin C. Proc Natl Acad Sci USA. 2007;104:4886-91.

36. Noh K, Lim H, Moon S, Kang JA, Wang JL, Lee D, et al. Mega-dose vitamin C modulates $\mathrm{T}$ cell functions in Balb/c mice only when administered during $\mathrm{T}$ cel activation. Immunol Lett. 2005;98;63-72.

37. Podmore ID, Griffiths HR, Herbert KE, Mistry P, Lunec J. Vitamin C exhibits prooxidant properties. Nature. 1998;392:559.

38. Södergren E, Nouroz-Zadeh J, Berglund L, Vessby B. Re-evaluation of the ferrous oxidation in xylenol orange assay for the measurement of plasma lipide hydroperoxides. J Biochem Biophys Methods. 1998;37:137-46.

39. Sogayar R. Ética na experimentação animal: consciência \& ação. Botucatu: Fundação de Estudos e Pesquisas Agrícolas e Florestais; 2006.

40. Ströhle A, Wolters M, Hahn A. Micronutrients at the interface between inflammation and infection - ascorbic acid and calciferol. Part 1: general overview with a focus on ascorbic acid. Inflamm Allergy Drug Targets. 2011;10:54-63.

41. Thurnham DI. Micronutrients and immune function: some recent developments. J Clin Pathol. 1997;50:887-91.

42. Wen JJ, Garg N. Oxidative modification of mitochondrial respiratory complexe in response to the stress of Trypanosoma cruzi infection. Free Radic Biol Med. 2004;37:2072-81.

43. Wen JJ, Yachelini PC, Sembaj A, Manzur RE, Garg NJ. Increased oxidative stress is correlated with mitochondrial dysfunction in chagasic patients. Free Radic Bio Med. 2006;41:270-6

44. Weyers A, Ugnia LI, Ovando HG, Gorla NB. Antioxidant capacity of vitamin C in mouse liver and kidney tissues. Biocell. 2008;32:27-31.

45. Wilkinson SR, Prathalingam R, Taylor MC, Horn D, Kelly JM. Vitamin C biosynthesis in trypanosomes: a role for the glycosome. Proc Natl Acad Sci USA. 2005;102:1164550 .

46. Witting LA. Vitamin E: do we need it? In: Wolinsky I, Hickson JF, editors. Nutrition and health. Topics and controversies. Boca Raton: CRC Press; 1995. p. 157-79.

Received: 9 January 2014

Accepted: 10 September 2014 